JOURNAL OF PHYSICS AND CHEMISTRY OF SOLIDS

\title{
High pressure Raman spectroscopy of spinel-type ferrite $\mathrm{ZnFe}_{2} \mathrm{O}_{4}$
}

\author{
Zhongwu Wang ${ }^{\mathrm{a}, \mathrm{b}, *}$, David Schiferl ${ }^{\mathrm{a}}$, Yusheng Zhao ${ }^{\mathrm{a}}$, H.St. C. O'Neill ${ }^{\mathrm{c}}$ \\ a Los Alamos National Laboratory, Los Alamos, NM 87545 USA \\ ${ }^{\mathrm{b}}$ Center for Study of Matter at Extreme Conditions (CeSMEC), Florida International University, VH-150, University Park, Miami, FL 33199 \\ USA \\ ${ }^{\mathrm{c}}$ Research School of Earth Sciences, Australian National University, Canberra, 2000, Australia
}

Received 22 April 2003; revised 13 August 2003; accepted 22 August 2003

\begin{abstract}
An in-situ Raman spectroscopic study was conducted to explore the pressure induced phase transformation of spinel-type ferrite $\mathrm{ZnFe}_{2} \mathrm{O}_{4}$. Results indicate that ferrite $\mathrm{ZnFe}_{2} \mathrm{O}_{4}$ initially transforms to an orthorhombic structure phase $\left(\mathrm{CaFe}_{2} \mathrm{O}_{4^{-}}\right.$ polymorph) at a pressure of $24.6 \mathrm{GPa}$. Such a phase transformation is complete at $34.2 \mathrm{GPa}$, and continuously remains stable to the peak pressure of $61.9 \mathrm{GPa}$. The coexistence of the two phases over a wide range of pressure implies a sluggish mechanism upon the spinel-to-orthorhombic phase transition. Upon release of pressure, the high pressure $\mathrm{ZnFe}_{2} \mathrm{O}_{4}$ polymorph is quenchable at ambient conditions.

(C) 2003 Elsevier Ltd. All rights reserved.
\end{abstract}

Keywords: C. High-pressure; C. Raman Spectroscopy; D. Phase transitions

\section{Introduction}

Spinel-type ferrites $\left(\mathrm{AFe}_{2} \mathrm{O}_{4}\right)$ are compounds that stabilize in the cubic spinel structure at ambient conditions. Considerable interest has been attracted in current studies due to the large diversity and the practical usefulness of their physical and chemical properties, including humiditysensing, oxygen-sensing, photoelectrical and super-paramagnetic as well as high temperature ceramic properties [1-4]. Given the recent achievement of successfully synthesizing the spinel type $\mathrm{Ge}_{3} \mathrm{~N}_{4}$ and $\mathrm{Si}_{3} \mathrm{~N}_{4}$ as the super hard materials in terms of the pressure tuning [5-7], it is also of particular interest to investigate the pressure induced postspinel phase transformations of those spinel solids, including spinel type ferrites, which may have potential applications in fields ranging from applied physics to material sciences.

$\mathrm{ZnFe}_{2} \mathrm{O}_{4}$ is one of the most important ferrite binary oxides with the spinel structure, and is usually used as a ferrimagnet with the strong dependence of magnetic properties on the

\footnotetext{
* Corresponding author. Tel.: +1-505-667-8839; fax: + 1-505665-2676.

E-mail address: z_wang@lanl.gov (Z. Wang).
}

state of chemical order and on the cation site occupancy in the materials $[3,4]$. The structural formula is generally written as $(\mathrm{ZnFe})_{x}[\mathrm{ZnFe}]_{2-x} \mathrm{O}_{4}$, where round and square brackets denote sites of tetrahedral (A) and octahedral [B] coordination, respectively, and where $x$ represents the degree of inversion defined as the fraction of the (A) sites occupied by $\mathrm{Fe}^{3+}$. Temperature and mechanical treatment mostly result in the appearance of the disorder of $\mathrm{Zn}$ and $\mathrm{Fe}$ ions over the tetrahedral and octahedral sites $[2,3,5]$, which in turn leads to a significant variation of the magnetic properties. Such a variation can be distinguished by the distinct temperatures of the antiferromagnetic long-range orders [3]. Recent studies on spinel $\mathrm{ZnCr}_{2} \mathrm{O}_{4}$ indicate that pressure tuning can also result in the presence of an order-disorder effect for the two metallic ions over the tetrahedral and octahedral sites [8,9]. Such an effect is thus expected to occur in the ferrite $\mathrm{ZnFe}_{2} \mathrm{O}_{4}$. Moreover, silicate spinel is considered as a key composition of the transition zone of the Earth [10]. Therefore, investigation of the high-pressure behavior of $\mathrm{ZnFe}_{2} \mathrm{O}_{4}$ as a similar spinel candidate may provide crucial implications for better understanding the dynamics of the Earth's interior. To date, only one in-situ X-ray diffraction study has been conducted to clarify the pressure induced 
phase transformation of $\mathrm{ZnFe}_{2} \mathrm{O}_{4}$ [11]. In this study, an orthorhombic phase was observed at pressures over $24 \mathrm{GPa}$, and such a phase was assigned to either the $\mathrm{CaTi}_{2} \mathrm{O}_{4}$ or $\mathrm{CaFe}_{2} \mathrm{O}_{4}$ structure [11]. Unfortunately, this study did not address the structural stability of the observed high-pressure phase upon release of pressure. Moreover, the corresponding structure assignment is still questionable because of the similarity between several orthorhombic structural polymorphs, including $\mathrm{CaTi}_{2} \mathrm{O}_{4}, \mathrm{CaFe}_{2} \mathrm{O}_{4}$ and $\mathrm{CaMn}_{2} \mathrm{O}_{4}$, which were observed in numerous spinel solids under pressure [11-15]. The XRD pattern obtained from the single postspinel phase can be reasonably refined to any of those structures. The key factor is still due to the lack of enough resolution of the X-ray diffraction pattern, even when collected by using the high-energy synchrotron source [12-14]. Raman spectroscopy is one powerful technique, which has often been used to identify the microscopic vibrations caused by the slight structural distortion, so it is very likely that using Raman spectroscopy will provide additional information for reconciling the existing structural disagreement. On the other hand, we have to consider the pressure induced negative effect that frequently occurs in pressure-Raman measurement. Application of super highpressure mostly results in a significant extinction of the Raman peaks, which in turn leads one to incorrectly assume the presence of a pressure-induced amorphization, rather than the formation of a crystal phase. As is well known, the substitute of cations with larger ionic radii in the spinel can ease the transition into higher coordination [15], and accordingly, the transition may take place at lower pressures compared to that in other spinels. Therefore, $\mathrm{ZnFe}_{2} \mathrm{O}_{4}$ is considered as a best candidate for checking the pressure induced phase transformation by Raman spectroscopy due to the larger ionic radius of iron (III). To this end, we were motivated to use Raman spectroscopy to clarify the highpressure behaviour of the ferrite $\mathrm{ZnFe}_{2} \mathrm{O}_{4}$.

In this paper, we present the phase transformation from $\mathrm{ZnFe}_{2} \mathrm{O}_{4}$ spinel to its high-pressure polymorph, which was confirmed by in-situ high pressure Raman spectroscopy. We also tested the structural stability of the high-pressure phase upon release of pressure. Combined with the previous X-ray diffraction data of several spinel solids, the results will be used to discuss and to elucidate the structure characteristics and the dynamics of the pressure induced phase transformation.

\section{Experimental}

The spinal $\mathrm{ZnFe}_{2} \mathrm{O}_{4}$ sample was synthesized by a high temperature flux method [16]. $\mathrm{ZnO}(4 \mathrm{~g}), \mathrm{Fe}_{2} \mathrm{O}_{3}(4 \mathrm{~g})$, $\mathrm{Na}_{2} \mathrm{WO}_{4}(23 \mathrm{~g})$ and $\mathrm{WO}_{3}(2 \mathrm{~g})$ were mixed together, and heated in a $100 \mathrm{ml} \mathrm{Pt}$ crucible with a lid to $1100{ }^{\circ} \mathrm{C}$. After $3 \mathrm{~h}$, the mixture was cooled at $6{ }^{\circ} \mathrm{C} / \mathrm{h}$ to $859^{\circ} \mathrm{C}$, at which temperature it was left for $40 \mathrm{~h}$, and then removed from the furnace. The flux was dissolved in warm water, with the help of an ultrasonic bath. The product consisted of euhedral octahedra of $\mathrm{ZnFe}_{2} \mathrm{O}_{4}, 2-10 \mu \mathrm{m}$ across. The $\mathrm{ZnFe}_{2} \mathrm{O}_{4}$ was a magenta-tinged brown color to the naked eye, and translucent brown $\mathrm{ZnO}$, which could be easily discerned under binocular lenses, was white (colorless in the grain mount), and usually contained one or two $(\sim 1 \mu \mathrm{m})$ inclusions of spinel. The recovered sample was analyzed by an electronic probe (CAMECA SX50 Mode) in the wavelength-dispersive mode, using standards of synthetic $\mathrm{Fe}_{2} \mathrm{O}_{3}$ and $\mathrm{ZnO}$. The average from five analyses was: $\mathrm{ZnO} 33.4 \pm 0.4 \mathrm{wt} \%, \mathrm{Fe}_{2} \mathrm{O}_{3}$ $65.9 \pm 0.30 \mathrm{wt} \%$, sum $99.3 \%$, molar ratio $\mathrm{ZnO} /$ $\mathrm{Fe}_{2} \mathrm{O}_{3}=0.995 \pm 0.013$. The coexisting oxides had $\mathrm{ZnO}$ $99.03 \pm 0.12$ and $\mathrm{Fe}_{2} \mathrm{O}_{3} 0.98 \pm 0.21$ (total 100.01, Analytical number $=11$ ). No Na or $\mathrm{W}$ could be detected in either phase. The $\mathrm{ZnO}$ was then removed by washing in dilute nitric acid. Aliquots of the single-phase spinel were loaded into $\mathrm{Pt}$ capsules, and equilibrated in air at $50{ }^{\circ} \mathrm{C}$ internals to $700{ }^{\circ} \mathrm{C}$ before quenching into water for this Raman study. X-ray diffraction indicates that the $\mathrm{ZnFe}_{2} \mathrm{O}_{4}$ crystallizes in a cubic structure with the unit cell parameter of $a=8.4416 \AA$. The $\mathrm{ZnFe}_{2} \mathrm{O}_{4}$ sample has a certain degree of disorder of $\mathrm{Fe}$ and $\mathrm{Zn}$ ions over the tetrahedral and octahedral sites with the inverse parameter of $x=0.10$ [16].

High pressure Raman measurements were conducted at room temperature by using a gasketed high pressure Diamond Anvil Cell (DAC) and Raman spectrometer in the back scattering configuration. $\mathrm{A} \mathrm{Ti}^{3+}$ : sapphire laser pumped by an argon ion laser was tuned at $785 \mathrm{~nm}$, which can effectively suppress the strong fluorescence of diamond. To avoid a heating effect, lasers were operated at $3 \mathrm{~mW}$ (after filer) to excite the sample, which was in contact with the low fluorescence diamond tips. Raman spectra were collected by using high throughput holographic imaging spectrograph with volume transmission grating, holographic notch filter and thermoelectrically cooled CCD detector (Physics Spectra) with the resolution of $4 \mathrm{~cm}^{-1}$ [17]. The spectrometer was regularly calibrated by the neon lines. Pressures were determined from the pressure-induced shift of the ruby fluorescence $\mathrm{R}_{1}$ line [18]. The sample was placed in a T301 steel gasket hole $60 \mu \mathrm{m}$ in initial thickness and $150 \mu \mathrm{m}$ in diameter with a few ruby chips as the pressure maker. The laser beam was focused on the sample with a spot size of $5 \mu \mathrm{m}$. To avoid a possible chemical reaction between the sample and the ruby caused by the laser heating, the exposure spot on the sample is only close to the ruby chip, in which the pressure difference does not exceed $\pm 0.5 \mathrm{GPa}$ from the exactly measured pressure. A 15 min exposure time was used for Raman collection at each run.

\section{Results and discussion}

$\mathrm{ZnFe}_{2} \mathrm{O}_{4}$ spinel has a cubic structure that belongs to the space group $O_{h}^{7}(F d 3 m)$. Although the full unit cell contains 
Table 1

Raman modes of spinel $\mathrm{ZnFe}_{2} \mathrm{O}_{4}$ observed at ambient conditions, their assignments and pressure dependences

\begin{tabular}{llll}
\hline Raman modes $\left(\mathrm{cm}^{-1}\right)$ & Assignment & Raman shift $\left(\mathrm{cm}^{-1} / \mathrm{GPa}\right)$ & Mode Gruneisen parameter $\left(\gamma_{0}\right)$ \\
\hline 221 & $\mathrm{~F}_{2 \mathrm{~g}}(1)$ & 1.31 & 0.99 \\
246 & $\mathrm{E}_{\mathrm{g}}$ & 0.77 & 0.52 \\
355 & $\mathrm{~F}_{2 \mathrm{~g}}(2)$ & 4.01 & 1.88 \\
451 & $\mathrm{~F}_{2 \mathrm{~g}}(3)$ & 3.95 & 1.46 \\
647 & $\mathrm{~A}_{1 \mathrm{~g}}$ & 2.76 & 0.71 \\
\hline
\end{tabular}

56 atoms $(Z=8)$, the smallest Bravais cell only consists of 14 atoms $(Z=2)$. As a result, the factor group analysis predicts the following modes in $\mathrm{ZnFe}_{2} \mathrm{O}_{4}$ spinel:

$$
\begin{aligned}
& \mathrm{A}_{1 \mathrm{~g}}(\mathrm{R})+\mathrm{E}_{\mathrm{g}}(\mathrm{R})+\mathrm{F}_{1 \mathrm{~g}}+3 \mathrm{~F}_{2 \mathrm{~g}}(\mathrm{R})+2 \mathrm{~A}_{2 \mathrm{u}}+2 \mathrm{E}_{\mathrm{u}}+4 \mathrm{~F}_{1 \mathrm{u}}(\mathrm{IR}) \\
& \quad+2 \mathrm{~F}_{2 \mathrm{u}}
\end{aligned}
$$

There are five first-order Raman active modes $\left(A_{1 g}+E_{g}+3 F_{2 g}\right)$, and all these modes were observed at ambient conditions, as shown in Table 1 and Fig. 1. In the cubic spinels including ferrites, the modes at above $600 \mathrm{~cm}^{-1}$ mostly correspond to the motion of oxygen in tetrahedral $\mathrm{AO}_{4}$ groups [8], so the mode at $647 \mathrm{~cm}^{-1}$ can be reasonably considered as $A_{1 g}$ symmetry. The other low frequency modes represent the characteristics of the octahedral sites $\left(\mathrm{BO}_{6}\right)$. The three first-order Raman modes at 355,451 and $647 \mathrm{~cm}^{-1}$ exhibit the broad characteristics. Nevertheless, the origin of the broadening of those firstorder modes remains unclear. The X-ray diffraction of this sample exhibits a slightly inverted structure [16], which implies that a certain amount of disorder of the $\mathrm{Zn}$ and $\mathrm{Fe}$ cations occurs in the tetrahedral and octahedral sites. Hence, the vibrations relating to these two types of cations at the same site may display two separated first-order Raman modes. If the two modes have very close vibrational frequencies, an overlapped broad peak with their average value should be observed. In this slightly inverted $\mathrm{ZnFe}_{2} \mathrm{O}_{4}$ spinel, $\mathrm{Zn}$ and $\mathrm{Fe}$ ions distribute at the same atomic crystal site, either the tetrahedral or octahedral, and result in the corresponding vibrations with different frequencies. Since these two vibrations have very close wavelengths, the three broad first-order Raman spectroscopic peaks were observed in this $\mathrm{ZnFe}_{2} \mathrm{O}_{4}$ spinel (Fig. 1). This is a plausible interpretation for the three observed broad first order Raman modes.

Fig. 2 presents the Raman spectra of $\mathrm{ZnFe}_{2} \mathrm{O}_{4}$ spinel at high pressure and at room temperature. Upon elevation of pressure to $24.6 \mathrm{GPa}$, we observed that one additional peak starts to grow at $655 \mathrm{~cm}^{-1}$, whereas six modes of the spinel phase either disappear or reduce their intensities. At a pressure of $34.2 \mathrm{GPa}$, all peaks belonging to the spinel phase completely disappear, and simultaneously another new mode begins to appear at $419 \mathrm{~cm}^{-1}$. The third new mode at $640 \mathrm{~cm}^{-1}$ appears at $56.6 \mathrm{GPa}$. The pressure dependences of the observed
Raman modes are plotted in Fig. 3. Of these Raman modes of the spinel phase, the two low-frequency modes $\left(\mathrm{F}_{2 \mathrm{~g}}\right.$ and $\left.\mathrm{E}_{\mathrm{g}}\right)$ display the pressure dependences of 1.31 and $0.77 \mathrm{~cm}^{-1} / \mathrm{GPa}$, and three high wavenumber modes (two $\mathrm{F}_{2 \mathrm{~g}}$ and one $\mathrm{A}_{\mathrm{g}}$ ) exhibit the pressure dependences of $4.01, \quad 3.95$ and $2.67 \mathrm{~cm}^{-1} / \mathrm{GPa}$, respectively. Such a pressure induced significant Raman variation suggests that a phase transformation initially takes place at 24.6 GPa, and finishes at $\sim 34.2 \mathrm{GPa}$. The three modes of the newly formed phase display the pressure dependences of $3.26,2.57$ and $2.26 \mathrm{~cm}^{-1} / \mathrm{GPa}$, respectively. Significant difference between the spinel and highpressure polymorph can be distinguished in which the newly observed modes do not emerge at the wavelengths, which are extracted from the pressure shifts of the spinel phase modes at the corresponding pressures. The coexistence of the two phases over a wide range of pressure of 24.6-34.2 GPa suggests that a sluggish transition mechanism contributes to this pressure-induced phase transformation.

Previous studies document two types of high-pressure behavior of spinels: one displays the formation of the single high-pressure polymorph [12-15], and another is

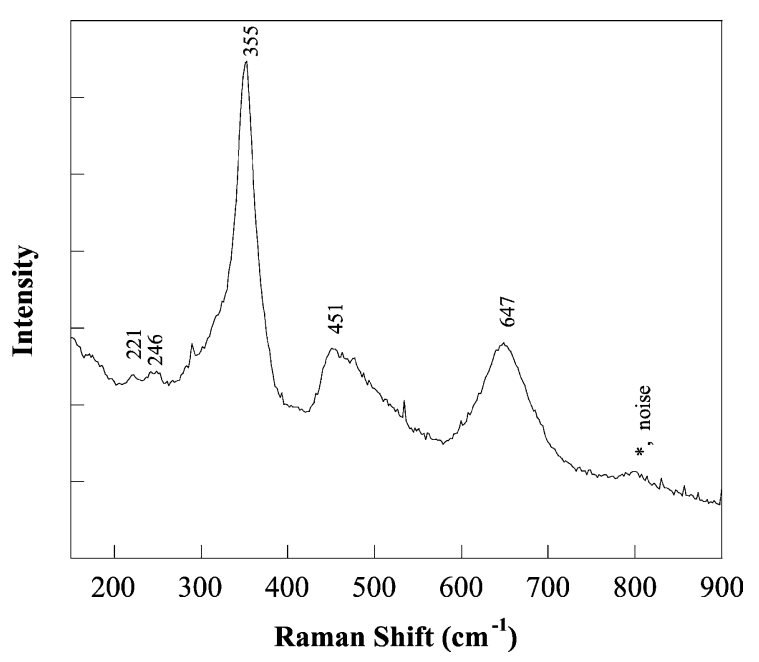

Fig. 1. The Raman spectrum of spinel ferrite $\mathrm{ZnFe}_{2} \mathrm{O}_{4}$ at ambient conditions. The peak at about $800 \mathrm{~cm}^{-1}$ is noise, because it keeps at the same wavelength at any pressure, and was also found at other studied samples. 


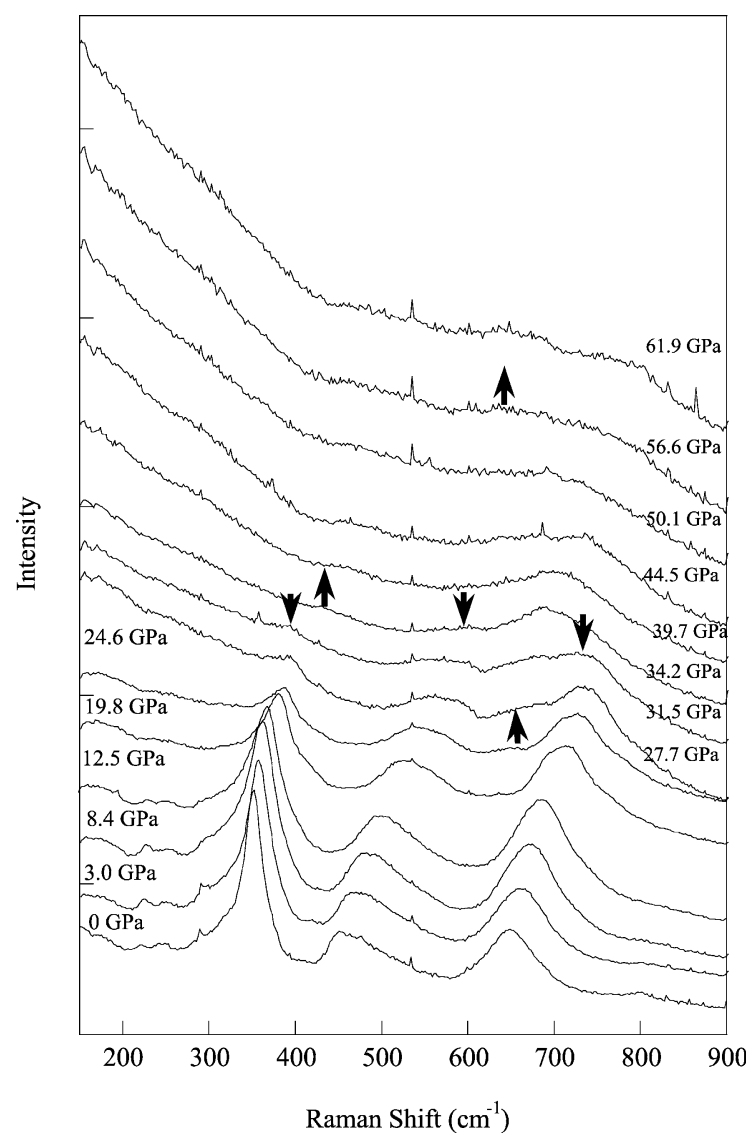

Fig. 2. Raman spectra of $\mathrm{ZnFe}_{2} \mathrm{O}_{4}$ under compression. The downward arrows $(\downarrow)$ and upward arrows $(\uparrow)$ represent the disappearance of spinel phase peaks and the occurrence of the new phase peaks.

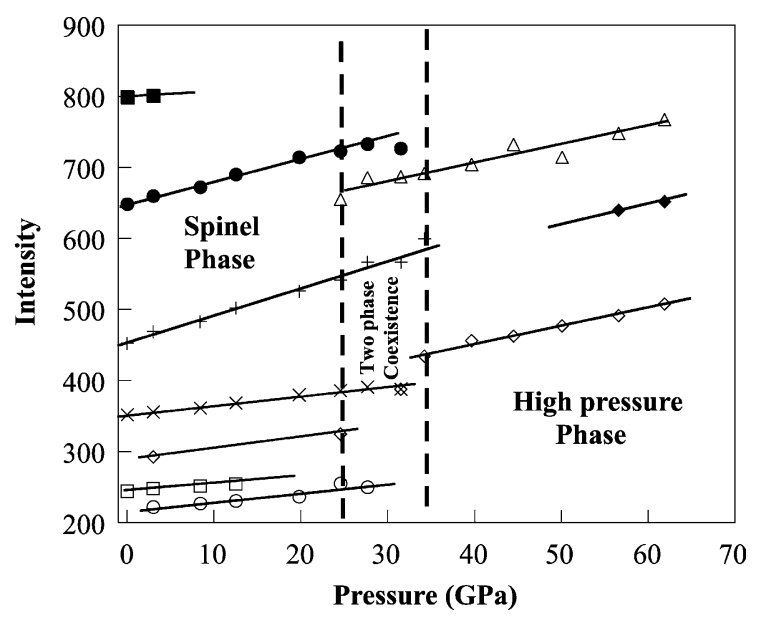

Fig. 3. The pressure dependences of the observed Raman modes from $\mathrm{ZnFe}_{2} \mathrm{O}_{4}$ at elevated pressures. decomposition $[15,19]$. This poses the question of whether the newly formed high-pressure phase is one single phase or a mixture of the decomposed constituents. The pressureinduced dissociation of the spinel-type solids $\left(\mathrm{AB}_{2} \mathrm{O}_{4}\right)$ has been investigated both experimentally and theoretically [19-21]. Ab initio simulations conducted by Catti et al. [19] reveal that spinel chromites $\left(\mathrm{MCr}_{2} \mathrm{O}_{4}: \mathrm{M}=\mathrm{Zn}, \mathrm{Mg}, \mathrm{Mn}\right)$ break down to a mixture of their constituent oxides $\left(\mathrm{MO}+\mathrm{Cr}_{2} \mathrm{O}_{3}\right)$ under pressure. In-situ pressure X-ray diffraction studies indicate that the spinel silicates, including $\mathrm{Mg}_{2} \mathrm{SiO}_{4}$ and $(\mathrm{Mg}, \mathrm{Fe})_{2} \mathrm{SiO}_{4}$, dissociate to the perovskite $\left[\mathrm{MgSiO}_{3}\right.$ and $\left.(\mathrm{Mg}, \mathrm{Fe}) \mathrm{SiO}_{3}\right]$ plus periclase phases $[\mathrm{MgO}$ and $(\mathrm{Mg}, \mathrm{Fe}) \mathrm{O}][20,21]$. In ferrite $\mathrm{ZnFe}_{2} \mathrm{O}_{4}, \mathrm{Fe}$ ion has a quite large average bond length in the $\mathrm{FeO}_{6}$ octahedron, which may result in the instability of the spinel structure under compression as compared to other spinels with small average-bond-length ions in the octahedral site. This was found in the pressure study of enstatite $\left(\mathrm{FeSiO}_{3}\right)$. The substitution of $\mathrm{Fe}$ ion in $\mathrm{A}$ site $\left(\mathrm{ASiO}_{3}\right)$ leads to a dissociation of enstatite $\mathrm{FeSiO}_{3}$ to $\mathrm{FeO}$ and $\mathrm{SiO}_{2}$, rather than the formation of a single $\mathrm{FeSiO}_{3}$ perovskite phase [20]. As a result, ferrite $\mathrm{ZnFe}_{2} \mathrm{O}_{4}$ is expected to dissociate as pressure increases. Thus, the most probable composition could be a mixture of $\mathrm{Fe}_{2} \mathrm{O}_{3}$ and $\mathrm{ZnO}$. High-pressure studies indicate that $\mathrm{Fe}_{2} \mathrm{O}_{3}$ crystallizes in the corundum $\left(\mathrm{Al}_{2} \mathrm{O}_{3}\right)$ structure at ambient conditions, and remains stable to pressures as high as $60 \mathrm{GPa}[21,22]$. With factor group theory, $\mathrm{Fe}_{2} \mathrm{O}_{3}$ should have seven Raman active modes $\left(2 \mathrm{~A}_{1 \mathrm{~g}}+5 \mathrm{E}_{\mathrm{g}}\right)$, which can be easily observed both at ambient and at high-pressure conditions [21]. $\mathrm{ZnO}$ stabilizes in the hexagonal structure $\left(C_{6 v}^{4}-P 6_{3} m c\right)$ below $10 \mathrm{GPa}[23,24]$, and four Raman active modes $\left(\mathrm{A}_{1}+\mathrm{E}_{1}+2 \mathrm{E}_{2}\right)$ are expected [25]. Upon pressurizing to $10 \mathrm{GPa}, \mathrm{ZnO}$ transforms to the rocksalt $\left(B_{1}\right)$ phase, which is Raman inactive [23-25]. In our Raman results, no Raman peak suggests the occurrence of the $\mathrm{Fe}_{2} \mathrm{O}_{3}$ phase. Therefore, we believe that ferrite $\mathrm{ZnFe}_{2} \mathrm{O}_{4}$ directly transforms to a single high-pressure phase, rather than a pressure-induced dissociation. This result may be caused by a large volumetric collapse between the spinel and the single high-pressure polymorph, in which a more negative free energy $(-P \Delta V)$, as compared to the free energy variation between the spinel and the mixture of $\mathrm{ZnO}$ and $\mathrm{Fe}_{2} \mathrm{O}_{3}$, contributes to the formation of the high-pressure polymorph.

High-pressure studies on $\mathrm{MgAl}_{2} \mathrm{O}_{4}$, which crystallizes in a perfect normal spinel structure, reveal that $\mathrm{MgAl}_{2} \mathrm{O}_{4}$ undergoes a phase transformation at pressures above $25 \mathrm{GPa}$, with a similar structure to that of calcium ferrite $\left(\mathrm{CaFe}_{2} \mathrm{O}_{4}\right)$ or calcium titanite $\left(\mathrm{CaTi}_{2} \mathrm{O}_{4}\right)$ [26,27]. Differences between the spinel structure and these two types of structures can be found, with atomic arrangements denser in the two new high-pressure phases. In these two high-density structures, the coordination around the cations is higher than that in the spinel, and $\mathrm{Ca}^{2+}$ is observed in a dodecahedral site $\left(\mathrm{CaO}_{8}\right)$, whereas $\mathrm{Fe}$ and $\mathrm{Ti}$ ions in octahedral sites. A more compact three-dimensional network is formed by edge 
and corner-sharing octahedra, with hollow channels parallel to the $\mathrm{c}$ axis, wherein the $\mathrm{Ca}$ cations are located. The difference between these two denser structures lies in a slight modification of the polyhedral linkage, which results in the presence of two types of $\mathrm{FeO}_{6}$ sites in $\mathrm{CaFe}_{2} \mathrm{O}_{4}$, a more symmetric $\mathrm{CaO}_{8}$ polyhedron in $\mathrm{CaTi}_{2} \mathrm{O}_{4}$. Most recently, a new assignment to a $\mathrm{CaMn}_{2} \mathrm{O}_{4}$ structure was found in the high-pressure phase of the spinel $\mathrm{Fe}_{3} \mathrm{O}_{4}$ [14]. The difference between this phase and other two structures $\left(\mathrm{CaFe}_{2} \mathrm{O}_{4}\right.$ and $\left.\mathrm{CaTi}_{2} \mathrm{O}_{4}\right)$ is that the $\mathrm{CaMn}_{2} \mathrm{O}_{4}$ structure is somewhat more distorted than the $\mathrm{CaFe}_{2} \mathrm{O}_{4}$, but a little more ordered than the $\mathrm{CaTi}_{2} \mathrm{O}_{4}$ structure [Havvik et al., 2001]. These three structures, $\mathrm{CaFe}_{2} \mathrm{O}_{4}, \mathrm{CaMn}_{2} \mathrm{O}_{4}$ and $\mathrm{CaTi}_{2} \mathrm{O}_{4}$, belong to the $D_{2 h}$ space group. The unit cell comprises four formula units $(Z=4)$. According to group theory, one could expect four types of Raman active modes $\left(\mathrm{A}_{\mathrm{g}}, \mathrm{B}_{1 \mathrm{~g}}, \mathrm{~B}_{2 \mathrm{~g}}, \mathrm{~B}_{3 \mathrm{~g}}\right)$ and three types of IR active modes $\left(B_{1 u}, B_{2 u}\right.$ and $\left.B_{3 u}\right)$. Based on the correlation between the Raman active modes of the two point groups $\left(O_{h}\right.$ and $\left.D_{2 h}\right)$, the $\mathrm{A}_{1 \mathrm{~g}}$ and $\mathrm{E}_{\mathrm{g}}$ modes in the $O_{h}$ representations transform to the $\mathrm{A}_{\mathrm{g}}$ modes in the $D_{2 h}$ representation, and the $\mathrm{F}_{2 \mathrm{~g}}$ modes transform to the $\mathrm{B}_{1 \mathrm{~g}}+\mathrm{B}_{2 \mathrm{~g}}+\mathrm{B}_{3 \mathrm{~g}}$ modes. As shown in Figs. 2 and 3 which were plotted with Raman data of $\mathrm{ZnFe}_{2} \mathrm{O}_{4}$, the parallel behavior of the novel mode at $655 \mathrm{~cm}^{-1}$ at $24.6 \mathrm{GPa}$ and the spinel $\mathrm{A}_{1 \mathrm{~g}}$ mode upon increase and release of pressure allows one to assume that the mode at $655 \mathrm{~cm}^{-1}$ is of $A_{\mathrm{s}}$ symmetry. Two additional new modes at 419 and $640 \mathrm{~cm}^{-1}$ initially arising at 34.2 and at $56.6 \mathrm{GPa}$ respectively, display similar behavior. They correlate to the $\mathrm{F}_{2 \mathrm{~g}}$ spinel mode and as such they should have $B_{(1,2,3) \mathrm{g}}$ symmetry. Upon release of pressure to $\sim 35 \mathrm{GPa}$, two novel modes start to emerge at 782 and $288 \mathrm{~cm}^{-1}$ (Figs. 5 and 6). Since these two modes have similar behavior to the $\mathrm{E}_{\mathrm{g}}$ and the overtone mode which were observed in this and other spinel solids, respectively [8], it is reasonable to assume that these two modes are of $A_{g}$ and $B_{(1,2,3) \mathrm{g}}$ symmetry. Nevertheless, the newly observed $\mathrm{B}_{(1,2,3) \mathrm{g}}$ mode is most likely caused by a slight distortion throughout the Brillouin zone due to the relaxation effect induced by the release of pressure. The above analyses and structural assignment have been confirmed by the recent in-situ high-resolution synchrotron $\mathrm{X}$-ray diffraction measurements [11]. Such an observation is also analogous to that observed from spinel $\mathrm{MgFe}_{2} \mathrm{O}_{4}[13$, 28]. In a pioneering XRD study [11], the X-ray diffraction pattern was successfully used to refine the high-pressure phase into either the $\mathrm{CaTi}_{2} \mathrm{O}_{4}$ or $\mathrm{CaFe}_{2} \mathrm{O}_{4}$ structure, but it was found that the XRD pattern obtained could also be well refined to the $\mathrm{CaMn}_{2} \mathrm{O}_{4}$ structure [13]. This implies that the current $\mathrm{X}$-ray diffraction resolution is still not sufficient to provide a satisfactory structural assignment for the observed high-pressure polymorph. We have collected the Raman spectra of the above three structure candidates [29]. It is shown that the Raman spectra of $\mathrm{CaMn}_{2} \mathrm{O}_{4}$ and $\mathrm{CaTi}_{2} \mathrm{O}_{4}$ are inconsistent with that of the high-pressure polymorph of $\mathrm{ZnFe}_{2} \mathrm{O}_{4}$. Since $\mathrm{CaFe}_{2} \mathrm{O}_{4}$ is also one end member of the ferrite solution, it is reasonable to assume that the high-pressure polymorph of $\mathrm{ZnFe}_{2} \mathrm{O}_{4}$ should have the $\mathrm{CaFe}_{2} \mathrm{O}_{4}$ structure. Moreover, the observed high-pressure phase from spinel $\mathrm{ZnFe}_{2} \mathrm{O}_{4}$ remains stable up to the peak pressure of $61.9 \mathrm{GPa}$ (Figs. 2 and 3).

The pressure dependences of the observed Raman modes for the spinel and high-pressure polymorphs were calculated to be $0.77-4.01 \mathrm{~cm}^{-1} / \mathrm{GPa}$ and $1.45-1.52 \mathrm{~cm}^{-1} / \mathrm{GPa}$, respectively (Fig. 3 and Table 1). With the bulk modulus calculated from previous X-ray diffraction data [11], the mode Gruneisen parameters $\left(\gamma_{i}\right)$ can be obtained by using the following equation:

$\gamma_{i}=-\left[\left(\mathrm{d} \ln v_{i}\right) /(\mathrm{d} \ln P)\right]=\left(B_{0} / v_{i}\right)\left(\mathrm{d} v_{i} / \mathrm{d} P\right)$

where $v_{i}$ is the $i$ th vibration mode of the spinel $(i=1-5)$; $P$ and $B_{0}$ are pressure and bulk modulus in GPa. At ambient conditions, the mode Gruneisen parameters $\left(\gamma_{0}\right)$ of the spinel phase are $0.52-1.88$ (Table 1). The mode Gruneisen parameters as a function of pressure are shown in Fig. 4. However, we could not calculate the Gruneisen parameters of the high-pressure polymorph of $\mathrm{ZnFe}_{2} \mathrm{O}_{4}$, due to the unavailability of its bulk modulus.

Upon release of pressure, the Raman spectra of highpressure polymorph of $\mathrm{ZnFe}_{2} \mathrm{O}_{4}$ were also collected (Fig. 5). High-pressure $\mathrm{ZnFe}_{2} \mathrm{O}_{4}$ polymorph maintains three significant modes visible under decompression. The pressure dependences of the three Raman modes are comparable to those observed during the compressed run (Fig. 6). Moreover, two more modes at 288 and $782 \mathrm{~cm}^{-1}$ were observed upon release of pressure to $\sim 35 \mathrm{GPa}$. These two modes exhibit quite low pressure-dependences, which are close to 0 (Fig. 6). The three original modes of the high-pressure phase do not change in their pressure dependences over the whole reduced pressure range. Therefore, this allows one to assume that the high-pressure orthorhombic polymorph of $\mathrm{ZnFe}_{2} \mathrm{O}_{4}$ is quenchable upon release of pressure to ambient conditions.

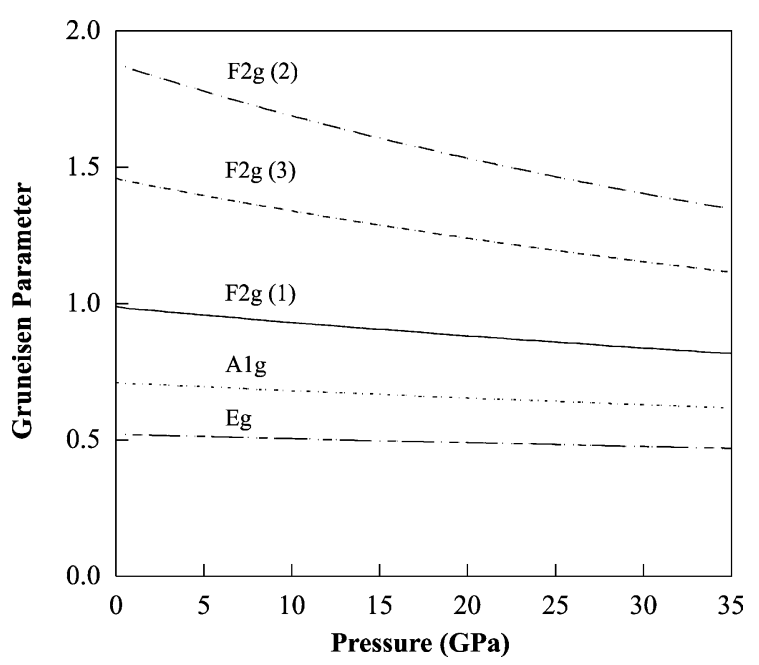

Fig. 4. The mode Gruneisen parameters of spinel $\mathrm{ZnFe}_{2} \mathrm{O}_{4}$ phase as a function of pressure. 


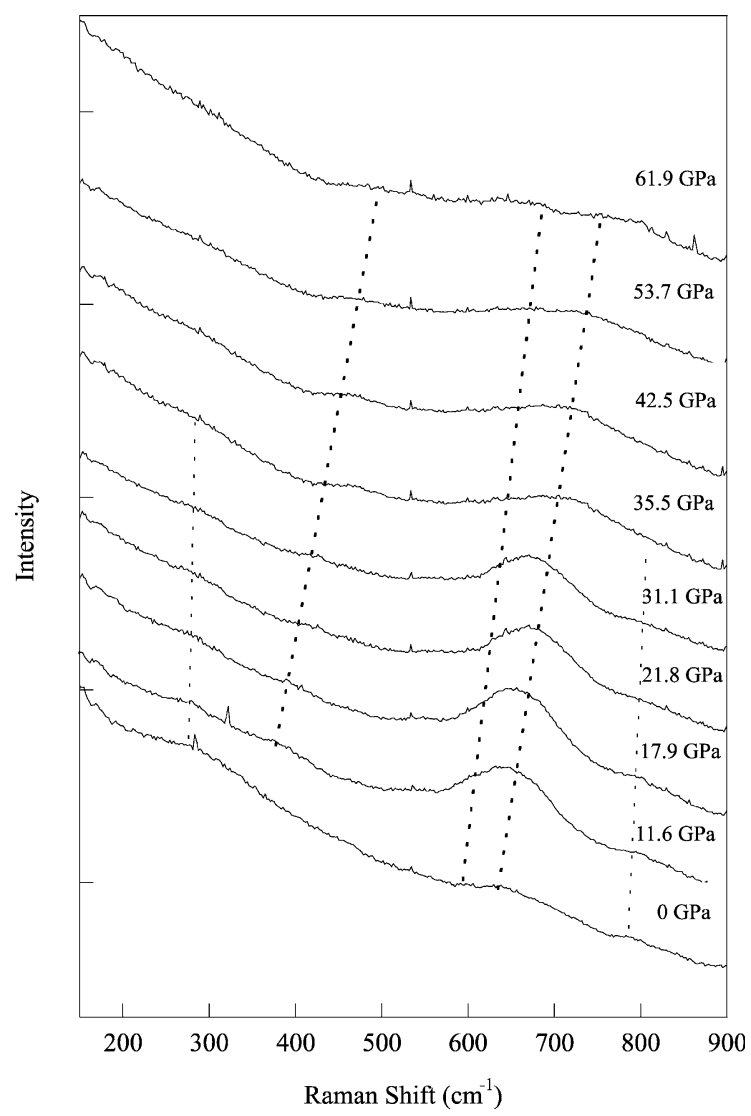

Fig. 5. Raman spectra of $\mathrm{ZnFe}_{2} \mathrm{O}_{4}$ at released pressures. The dotted lines guide eyes.

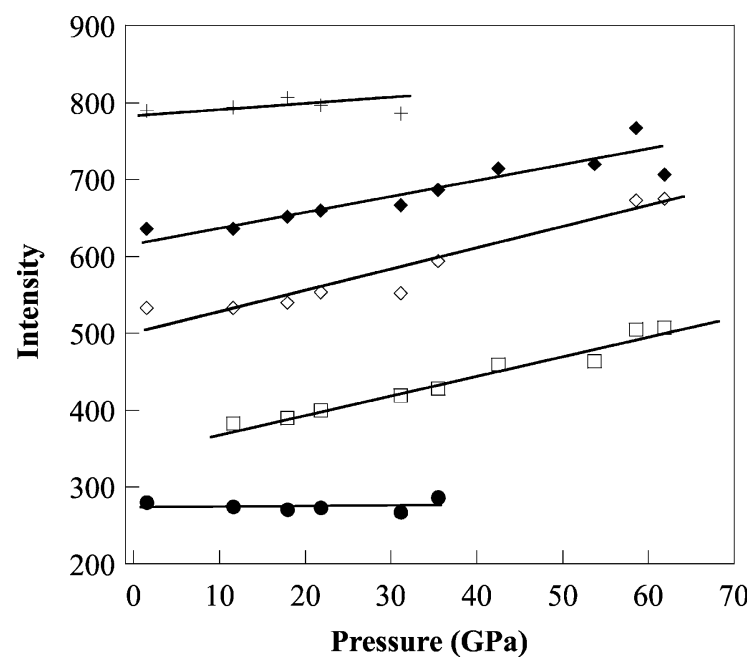

Fig. 6. The pressure dependences of the observed Raman modes from $\mathrm{ZnFe}_{2} \mathrm{O}_{4}$ under decompression.

\section{Conclusion}

An in-situ Raman spectroscopic study was carried out to explore the pressure induced phase transformation in spinel-type ferrite $\mathrm{ZnFe}_{2} \mathrm{O}_{4}$ to pressures of $61.9 \mathrm{GPa}$. Spinel $\mathrm{ZnFe}_{2} \mathrm{O}_{4}$ transforms to an orthorhombic structure phase at a pressure of $24.6 \mathrm{GPa}$, which was assigned to the $\mathrm{CaFe}_{2} \mathrm{O}_{4}$ structure. This high pressure $\mathrm{ZnFe}_{2} \mathrm{O}_{4}$ polymorph remains stable to $61.9 \mathrm{GPa}$. Upon release of pressure to ambient conditions, the high-pressure phase is quenchable.

\section{Acknowledgements}

We appreciate the financial support from Director funded Fellowship of Los Alamos National Laboratory, which made this study possible. Special thanks go to Dr Peter Lazor for invaluable discussion.

\section{References}

[1] W.F.J. Fontijn, P.J. van der Zaag, L.F. Feiner, R. Metselaar, M.A.C. Devillers, J. Appl. Phys. 85 (1999) 5100-5105.

[2] W. Schafer, W. Kockelman, A. Kirfel, W. Potzel, F.J. Burghart, G.M. Kalvius, A. Martin, W.A. Kaczmarek, S.J. Campbell, Mater. Sci. Forum 321 (2000) 802-807.

[3] H.H. Hamdeh, J.C. Ho, S.A. Oliver, R.J. Willey, G. Oliveri, G. Busca, J. Appl. Phys. 81 (1997) 1851-1857.

[4] S.A. Oliver, H.H. Hamdeh, Phys. Rev. B 60 (1999) 3400-3405.

[5] E. Soignard, M. Somayazulu, H.K. Mao, J.J. Dong, O.F. Sankey, P.F. McMillan, Solid State Commun. 120 (2001) 237-242.

[6] A. Zerr, G. Miehe, G. Serghiou, M. Schwarz, E. Kroke, R. Riedel, H. Fuess, P. Kroll, R. Boehler, Nature 400 (1999) 340-342.

[7] G. Serghiou, G. Miehe, O. Tschauner, A. Zerr, R. Boehler, J. Chem. Phys. 111 (1999) 4659-4662.

[8] Z.W. Wang, P. Lazor, S.K. Saxena, G. Artioli, J. Solid State Chem. 165 (2002) 165-170.

[9] J. Wittlinger, S. Werner, H. Schulz, Acta Crystalallogr. B 54 (1998) 714-721.

[10] S.H. Shim, T.S. Duffy, G. Shen, Nature 411 (2001) 571-574

[11] D. Levy, A. Pavese, M. Hanfland, Phys. Chem. Mineral 27 (2000) 638-644.

[12] Y.W. Fei, D.J. Frost, H.K. Mao, C.T. Prewitt, D. Hausermann, Am. Mineral. 84 (1999) 203-206.

[13] D. Andrault, N. Bolfan-Casanova, Phys. Chem. Mineral. 28 (2001) 211-217.

[14] C. Haavik, S. Stolen, H. Fjellvag, M. Hanfland, D. Hausermann, Am. Mineral. 85 (2000) 514-523.

[15] A.E. Ringwood, A. Reid, Earth Planet Sci. Lett. 6 (1969) 245-250.

[16] H.S.C. O'Neill, Eur. J. Mineral 4 (1992) 571-580.

[17] Z.W. Wang, S.K. Saxena, Solid State Commun. 118 (2001) $75-78$. 
[18] H.K. Mao, J. Xu, P.M. Bell, J. Geophys. Res. 91 (1986) 4673-4681.

[19] M. Catti, F. Freyria, C. Zicovich, R. Dovesi, Phys. Chem. Mineral. 26 (1999) 389-395.

[20] A. Navrotsky, Physics and Chemistry of Earth Materials, Cambridge University Press, Cambridge, 1994, p. 417.

[21] S. Shim, T.S. Duffy, Am. Mineral. 87 (2002) 318-326.

[22] M.P. Pasternak, G.K. Rozenberg, G.Y. Machavariani, O. Naaman, P. Taylor, R. Jeanloz, Phys. Rev. Lett. 82 (1999) 4663-4666.

[23] J.M. Recio, M.A. Blanco, V. Luana, R. Pandey, L. Gerward, J.S. Olsen, Phys. Rev. B 58 (1998) 8949-8954.
[24] F. Decremps, J. Zhang, R.C. Liebermann, Europhys. Lett. 51 (2000) 268-274.

[25] F. Decremps, J. Pellicer-Porres, A.M. Saitta, J.C. Chervin, A. Polian, Phys. Rev. B 65 (2001) 092101.

[26] N. Funamori, R. Jeanloz, J.H. Nguyen, A. Kavner, W.A. Caldwell, K. Fujino, N. Miyajima, T. Shinmei, N. Tomioka, J. Geophys. Res. 103 (1998) 20813-20818.

[27] M. Catti, Phys. Chem. Mineral. 28 (2001) 729-736.

[28] Z.W. Wang, S.K. Saxena, P. Lazor, H.S.C. O’Neill, Mater. Res. Bull. 37 (2002) 1589-1602.

[29] Z.W. Wang, S.K. Saxena, J.J. Neumeier, J. Solid State Chem. 179 (2003) 382-389. 